\title{
Preschool English Teachers' Practices in Early Literacy Instruction: A Multiple Case Study
}

\author{
Adelina Asmawi ${ }^{1} \&$ Nazila SeyedHendi ${ }^{1}$ \\ ${ }^{1}$ Faculty of Education, University Malaya, Kuala Lumpur, Malaysia \\ Correspondence: Nazila SeyedHendi, Faculty of Education, University Malaya, Kuala Lumpur, Malaysia. Tel: \\ 60-10-284-7540.
}

Received: August 30, 2016

Accepted: September 21, 2016

Online Published: September 27, 2016

doi:10.20849/aes.v1i2.72

URL: http://dx.doi.org/10.20849/aes.v1i2.72

\begin{abstract}
The practices preschool teachers implement in their classrooms are vital in their students' literacy development. Preschool teachers are always expected to implement research-based literacy practices to make sure children are ready to learn when they enter school. This multiple-case study intended to address four non-native in-service preschool English teachers' practices in early literacy instruction. Data collection involved field notes and videotaping of classroom practices along with interviews and documents from ten full English lesson observations in each classroom. Data analysis began with identifying teachers' practices. A cross case analysis was also conducted. The results showed that even when four teachers were in the same school district, using different curriculum, and supported by the different principal, each interpreted and enacted literacy policy differently. The overall conclusion generated from the results of the data analyses is that though teachers and preschool principals perceived that they were effectively applying early English literacy instruction, there was actually a divide between what teachers believed and what they implemented (their actual practice) in their classrooms. Besides, there was not enough interaction between teacher and children. However, the four preschool teachers mentioned in their interviews that they would like to be friends with their students.
\end{abstract}

Keywords: English language learner (ELL), early literacy instruction, ESL teachers, multiple case study

\section{Introduction}

Today preschool teachers are educating a diverse population of children, with many from homes where English is not the first language. In light of this growing number of English Language Learners (ELLs) in preschool, researchers have investigated ways to support ELLs' emergent literacy development. Preschool teachers have a significant role in children's literacy development. "They actually have the power to influence early literacy skill development and potentially impact children's later success in school" (Dennis and Horn, 2011, p. 30). Sandvik, Van Daal and Ader (2013) define emergent literacy as the emergence of literacy-related behaviors due to both direct instruction and social interaction. Advocates of the emergent literacy perspective acknowledge that children's early literacy emerges through primarily social interaction.

Regarding teachers' early literacy instruction, Snow, Griffin, Burns, and the NAE Subcommittee on Teaching Reading (cited in Porche, Pallante \& Snow, 2012) state that how teachers practice instruction is as significant as the content they provide in their classroom, and to certify that all teachers know how to implement outstanding literacy instruction, constant professional development and support are critical. Pray (2010) believes that "most local ESL teachers have little experience working with ELLs, learning a second language, and working with students from diverse cultural and linguistic backgrounds" (p. 217).

Furthermore, considering the role of preschool teachers in developing early literacy and identifying this role in early childhood education curriculum are critical. Paciga, Hoffman and Teale (2011) worry that drill-and-skill activities and practices replace some richer language and literacy activities.

Therefore, effective classroom teachers need a variety of instructional methods to meet the diverse needs of their students. Incorporating direct instruction with developmentally appropriate practices provide opportunities for children to engage in a multitude of hands-on literacy activities. 


\subsection{Preschool Teachers' Practices and Curriculum}

In 2003, the Malaysia Ministry of Education (MOE) set the National Preschool Curriculum which all preschools, public and private are required to follow. The National Preschool Curriculum is based on the principles of Rukun Negara (Malay for "National Principles") which is the Malaysian declaration of national philosophy and the National Philosophy of Education; and aims to develop social, intellectual, physical, spiritual and aesthetic values in children (Malaysian International ECEC Conference,2009).

Along with the National Preschool Curriculum and the National Philosophy of Education, two famous preschool curricula are used in most private preschools in Malaysia; IPC and Montessori. Both curricula consider interaction and play crucial to develop early literacy in young children. On the contrary, it is actually recognized that the actual practices of teachers contradict with the curriculum. It means that there is a contradiction between preschool curriculum focusing on social interaction between teacher and children (and the role of play) and the actual practices that preschool teachers implement in their classrooms. As Jensen (2011) considers that how to implement early literacy teaching in relation to the policy domains (school effectiveness), curricula and indicators, and the children's own perspectives seems a real challenge. Therefore, the current study aimed to fill the gap in literature which is the effective early language and literacy instruction for ELLs and the way preschool teachers implement social interaction into practice. Dickinson and McCabe (cited in Scull, Brown \& Deans, 2009) confirm that teachers are uncertain as how to construe literacy and how to decode existing knowledge and teaching strategies into practice.

Therefore, it is essential to consider the significance of early childhood curriculum in leading preschool teachers to implement an effective early language and literacy instruction. Making a structured curriculum and specifying what preschool teachers can teach might help them to have a positive impact on the literacy development of children.

\subsection{Theoretical Basis for the Study}

The current study drew on two theories; Ecological Theory and Child Development (Bronfenbrenner, 1979; Tseng \& Seidman, 2007) and social constructivist theory (Vygotsky, 1978).

Ecological Theory and Child Development highlights the significance of teachers' critical reflection on their practices, the inter-relationships of; a) educational research into young children's learning and development, language development and early literacy learning, b) beliefs, principles and practices, including the teachers role, the image of the child and intentional teaching practices c) rich conversations and interactions in the kindergarten learning environment d) supportive partnerships with children, parents, families and communities e) inclusive learning environments and children's capacity to experiment and engage with literacy through play f) connections with children's prior language and literacy experiences, family priorities for supporting literacy, children's interests and strengths and community and family opportunities for language and literacy learning.

Additionally, this research was informed by a social constructivist theory since "our understandings of literacy are informed by a social constructivist perspective" (Oldfather \& Dahl, 1994, p. 140). This view emphasizes the critical role of the more knowledgeable other, preschool teachers, in facilitating learning.

Additionally, Social Constructivist theory emphasizes that Language and literacy are social events which do not only require skills, knowledge and understanding, but also involve complex interactions and responses. Literacy is developed through the interactions in classroom discourse, family and the larger community and culture. This participation in interactions has an important effect on the individual's sense of self as a reader and writer. Lev Vygotsky's (1978) work on children's language development has greatly influenced how educators understand language and literacy learning, and his theories continue to impact early childhood education and teacher professional development. At the core of Vygotsky's theory was the idea that child development was the result of interactions between children and their social environment.

\subsection{Purpose of the Study}

The purpose of this study was to examine the early English literacy practices of four non-native in-service preschool teachers through the association of their strategies and approaches they applied in their classrooms. Gaining an understanding of actual practices in early English literacy helps teachers open up the world of communication for students by expanding the potential for students to share thoughts and needs (Shagoury, 2009).

Given the acknowledgement of preschool teachers' practices and their role in early literacy instruction specifically early English literacy, investigation in this area was not only favorable, but at this junction, was warranted. Therefore, the following questions guided the current research: 
Question 1: What early English literacy instruction is provided by preschool teachers in the classrooms?

Question 2: How do preschool teachers implement social interaction into practice?

\section{Method}

A qualitative research design was employed in the current study. It also adopted a multiple-case study in which "multiple cases are described and compared to provide insight into an issue" (Creswell, 2012, p. 465). In order to have a better understanding of the four selected items, several sources of information were gathered. They included semi-structured interviews, classroom observations and reviewing syllabuses, teachers' lesson plans or worksheets.

\subsection{Participants}

In the present study, kindergartens' principals were interviewed to explore the type of curriculum they were using in their centers. Also, their view- points concerning the materials provided to ELLs and teachers' role on developing early English literacy in young children was examined.

Principal 1 (Montessori): She obtained a degree in Economics and has been a teacher for eleven years. She is being a principal for thirteen years. She qualified teachers based on their teaching experiences (1-2 years). She believed preschool teachers should be patient and love children. She considered social interaction important in early childhood education. In addition, she stated that it is quite good for children to share experiences and encourage children to speak up through telling their stories.

Principal 2 (IPC): She has got diploma and worked as a teacher for 2 years then started working in IPC preschool as a principal for a few months. She mentioned that all teachers need to prepare lesson plans and they should not necessarily follow the same specific teaching method or approach. It all depends on the kids' capability. She also said that there should be a friendly interaction between teacher and the students. In her opinion teachers can be professionally developed through providing teacher-training assessment.

Additionally, four non-native in-service preschool teachers were selected to participate in this study from the list of teachers in two private kindergartens in Malaysia. Maria, after obtaining diploma in science passed some short Montessori Set courses. She also passed some courses in Phonics. She had been teaching at the present kindergarten for three years. She used to be a bible teacher but started working with kids because of passion. Sally, a young preschool teacher in Montessori kindergarten, had passed some courses of Montessori in Segi College and obtained her diploma. She had also received Kusus Asos Kanak Kanak certificate which was obtained in order to open a center. In addition, she got the certificate in First Aid which she believed it was quite important for teaching. She had been working for five years as a teacher but working at the current kindergarten around a year. Carla, the preschool teacher in IPC liked to work with kids and decided to get into teaching and early childhood education because of kids. She had got degree in architecture but was currently taking master in Early Childhood Education. She had been a preschool teacher for eight months. Maya, another young preschool teacher in IPC kindergarten, had studied in Modern Montessori International in Subang; a suburban city in the Klang Valley, Selangor, Malaysia. She had also obtained the Montessori teaching diploma from London. She had been working for eight months as a teacher. Therefore, her teaching limited only to this current kindergarten. The principals of kindergartens were approached to select teachers and for permission to conduct the study at their kindergarten.

For the privacy of participants, each potential participant was contacted only after the researcher had an initial exchange with the preschool principal regarding the teachers' participation.

\subsection{Research Sites}

Two private preschools under the franchises of IPC and Montessori were considered as the research sites. The selection of these two preschools for this project was based on three factors. First, they are highly popular and recognized in Malaysia. Second, both preschools' curriculum considers social interaction and play crucial in developing early literacy in young children. Third, the demography of the kindergartens provided the researcher with an important venue for examining the role of the practices of early English literacy preschool teachers and early literacy curriculum on developing early literacy on ELLs. The principals in both kindergartens tried to create a classroom environment based on their specific curriculum and provide teaching materials.

\subsection{Data Collection Procedures}

Throughout this research, the data collection procedures reflected the socio-constructivist lens in which classroom interactions were viewed. Several types of qualitative instruments were used to collect data on how teachers implement the materials in their classrooms and how the interactions take place. As a result, the present research utilized the following sources of data: 
- Semi-structured interviews: First, the principals of kindergartens were interviewed (Appendix A). The purpose of this interview was to identify their views regarding early English literacy and get information about the curriculum and syllabus which were used in their kindergartens.

Next, each teacher was interviewed following an interview protocol (Appendix B). Some interview questions originated from a study of preschool literacy beliefs in Australia (Ure and Raban, 2001) and a study of Lynch (2009). The questions were modified and rephrased depending on the participants' attitudes or mood. The interviews were conducted before the classroom observations to elicit information and collect appropriate data. During the interviews the researcher took notes about the most remarkable features stated by the principals and ESL teachers, the variations and unplanned questions.

- Classroom observations: The researcher asked kindergarten principals to obtain permission to observe each preschool teacher in their class. The descriptive observational visits (Appendix C) were occurred during regularly scheduled English literacy instruction which lasted no longer than ten sessions. The purpose of the instrument was to collect data that reflects classroom instruction. The next type of observation was focused observations (Appendix D). Focused observations limit the scope of area in the investigation and occur after the descriptive observations have occurred (McGoun, 2007). Focused observations for this study included an examination of the literacy practices and social interaction that four preschool teachers implemented in their classrooms, students' behavior toward the activities and each other, and student growth.

During the observation, the observer took field notes and observations were video-recorded. The researcher met each teacher at the end of the final visit to debrief about comments made in observations the researcher had noted during visits. This debriefing session provided an opportunity for the preschool teacher to ask questions or make further comments. The purpose of these observations was to better understand the four teachers' classroom routines.

- Document review (i.e. syllabuses, schemes of work, lesson plans and worksheets): Another important source of information was the analysis of existing documents such as reports, data files, lesson plans and other written artifacts in order to complement the information from class observations and interviews. This helped to better understand the program and establish a connection among all different types of data. They were processed using the drawing features of Microsoft Word 10. Written lesson plans were compared with the observed lessons to match the content. They were used to explore to what extent the lesson plans' content matched teachers' actual practices.

\subsection{Data Analysis}

The last step involved looking across the four cases to analyze the four preschool teachers' stories relating to the two research questions. Through this process the researcher looked for details to show the distinctions and similarities of these teachers' beliefs about early English literacy instruction. She then followed the same procedures for their literacy practices, this time searching for patterns of practice, again looking for ways that Maria, Sally, Carla and Maya implemented interactions in the classroom across instructional events.

It is imperative that the material under scrutiny is analyzed in a methodical manner if qualitative research is to yield meaningful and useful results. "Thematic analyses seek to unearth the themes salient in a text at different levels, and thematic networks aim to facilitate the structuring and depiction of these themes" (Attride- Stirling, 2001, p.387). "The procedure of thematic networks provides a technique for breaking up text, and finding within it explicit rationalizations and their implicit signification (p.388)".

The analysis of the data collected over the course of the present research was guided by the questions. An analysis of the data found four major themes. The data from each teacher was coded separately. Field notes were read in their entirety and coded. Observations, interviews and lesson plans collected found a) emergent literacy routines or activities, b) instructional practices, c) literature in the classroom and d) teacher-student social interaction to be the most significant themes in both kindergartens.

\section{Results}

The four preschool teachers' actual practices were observed based on two sections of observation checklist (Appendix C \& D) which is demonstrated as follows:

\begin{tabular}{|c|c|c|c|c|}
\hline & Maria & Sally & Carla & Maya \\
\hline Interaction & & & & \\
\hline
\end{tabular}


Teacher minimizes her role in conducting the activities.

She organizes the activities so they are suitable for real interaction among the students.

The activities maximize student involvement.

The activities promote spontaneity or experimentation on the part of the learner.

The activities generally transfer attention away from "self" and outward toward a task".

The activities are organized to insure a high success rate, leaving enough room for error to make the activity challenging.

$\begin{aligned} & \text { She is not overly concerned with error correction. She concentrates on } \\ & \text { what the students are saying (content). }\end{aligned}$
.

\begin{tabular}{|c|c|c|c|c|}
\hline Language & & & & \\
\hline The activity is focused. & $x$ & $x$ & $x$ & $x$ \\
\hline $\begin{array}{l}\text { The content or the skill presented will be easily transferrable for use } \\
\text { outside the class. }\end{array}$ & $x$ & & $x$ & \\
\hline
\end{tabular}

The activity is geared to the proficiency level of my class or slightly beyond.

The content of the activity is not too sophisticated for my students.

Teacher makes the content of the activity relevant and meaningful to the students' world.

The practices of the four teachers related to literacy components including social interaction, print awareness, alphabet knowledge and phonological awareness are illustrated in the following observation checklist:

\begin{tabular}{|c|c|c|c|c|}
\hline & Maria & Sally & Carla & Maya \\
\hline \multicolumn{5}{|l|}{ Social Interaction } \\
\hline $\begin{array}{l}\text { Teacher promotes the students to attend during literacy activities using eye } \\
\text { gaze gestures, voice, and personal communication device. }\end{array}$ & $x$ & $x$ & $x$ & $x$ \\
\hline $\begin{array}{l}\text { She helps the students to attend to (by reaching, pointing or looking) to } \\
\text { pictures, symbols and text. }\end{array}$ & $x$ & $x$ & $x$ & $x$ \\
\hline $\begin{array}{l}\text { She guides students to demonstrate understanding or personal connection } \\
\text { during favourite part of story by commenting on and/or relating to personal } \\
\text { experiences, responding to questions about story and asking questions about } \\
\text { story. }\end{array}$ & $x$ & $x$ & $x$ & $x$ \\
\hline \multicolumn{5}{|l|}{$\begin{array}{l}\text { She promotes the students to retell a part of the story with an activity (e.g., } \\
\text { arrange picture cards, act out, retell in own words) or in a sequence. }\end{array}$} \\
\hline \multicolumn{5}{|l|}{ Print Awareness } \\
\hline $\begin{array}{l}\text { Teacher encourages the students to demonstrate awareness of print by } \\
\text { attending, eye gaze, pointing, vocalizations or talking. }\end{array}$ & $x$ & $x$ & $x$ & $x$ \\
\hline \multicolumn{5}{|l|}{ She helps students to connect print to speech/language. } \\
\hline $\begin{array}{l}\text { She guides them to understand basic concept of printed word (e.g., by } \\
\text { connecting picture or object with printed word). }\end{array}$ & & & & \\
\hline
\end{tabular}


Teacher encourages students to:

1. explore alphabet materials

2. know that printed/tactual letters are different from pictures and other representations

\begin{tabular}{l} 
3. recognize first letter in own name \\
$\begin{array}{l}\text { 4. identify specific letters in own name, other important names or high } \\
\text { frequency words }\end{array}$ \\
\hline $\begin{array}{l}\text { Teacher helps students to: } \\
\text { 1. recognize other letters in other words }\end{array}$ \\
\hline 2. identify name of many letters (indicate number of letters) \\
\hline Phonological Awareness
\end{tabular}

Teacher assures that students:

1. participate in word play such as finger plays

\begin{tabular}{llll}
\hline 2. follow rhythmic patterns in poems, music and stories & & \\
\hline 3. recognize basic sounds of some letters (indicate number or specific & $\times$ & $\times$ & $\times$
\end{tabular}

4. repeat rhythmic patterns in poems, music and stories

\begin{tabular}{l}
\hline 5. demonstrate awareness that different words begin with the same sound \\
6. identify initial letter sounds of at least 20 letters
\end{tabular}

The program curricula, Montessori and IPC were also part of the document analysis, with attention paid to curricular guidelines and expectations for language and literacy instruction and experiences. Curricular guidelines were used to juxtapose teacher beliefs and practices with the stated goals and practices of the curriculum. Document analysis was conducted on curriculum used by the program to obtain information about the language and literacy goals of the curriculum and how they are to be implemented in practice. Information on curricular guidance regarding the learning environment, activity settings, and strategies for dual language learners was also reviewed. Some documents samples and worksheets are illustrated in Appendix E.

In contrast to the structured practices of syllables and rhymes observed over three months rarely did the researcher see teachers draw children's attention to sounds during work time when children were involved in play at various centers. Based on observation checklist, teachers did not assure that students demonstrate awareness that different words begin with the same sound or repeat rhythmic patterns in poems, music and stories.

To all four teachers especially in IPC preschool, alphabet knowledge was the main component of early English literacy instruction. There were not specific alphabet materials. They just used some worksheets for kids to trace and colour them. They attempted to encourage students to recognize the first letter in their own names and some other names but they did not help them to know that printed letters are different from pictures and other representations.

Actually, through regular reading of stories, flash cards and sound boxes, teachers ensured that the children encountered print. However, they rarely made explicit connections for the children between the symbols and the printed words despite the fact that for children to learn print concepts, explicit reference to print is essential (Lovelace \& Stewart, 2007). One of the ways teachers overtly demonstrated for students' knowledge of the alphabet was through structured lessons designed to help children recognize letters. As a matter of fact, teachers tried to encourage the students to demonstrate the awareness of print by pointing and vocalizations but did not help them to connect the print to speech or language.

Besides, teachers guided students to demonstrate understanding or personal connection during favourite part of story by commenting on and/or relating to personal experiences, responding to questions about story and asking questions about story. However, they did not promote the students to retell a part of the story with an activity (e.g., arrange picture cards, act out, retell in own words) or in a sequence. 


\section{Discussion}

The preschool teachers in the current study clearly knew the rhetoric of early childhood education and through play they could encourage children. However, the data in the present study points to the fact that it is hard to implement all the teaching theories into actual practice. Farrell (cited in Farrell \& Ives, 2015) mentioned that for teachers to be more aware and understand how their beliefs can affect their practices, it is necessary to put tacitly held beliefs in words.

Besides, teacher-child interaction is an important factor affecting effective implementation of the related practices for establishing a language context. . Berry and O'Connor (cited in Nurmi \& Kiuru, 2015) emphasized that "children with a higher-quality teacher-child relationship demonstrated greater social skills from kindergarten through to sixth grade than their peers with lower quality relationships" (p. 450). However, there were lack of activities preschool teachers implemented to promote English literacy in young children.

Some teachers tried to communicate and speak with children around literacy activities. While parts of the schedule may have constrained their practice, they used particular time periods (during story time) to get children to talk. The only limitation was that two teachers in IPC preferred to work with kids one-on-one or individually. In contrast, the other two teachers in Montessori have limited time to do that so mostly they worked in large groups. However, Baroody and Diamond (2016) emphasize that "preschoolers aged 3 to 5 years are usually required to participate in a group time activity (i.e. an activity that is initiated and led by the teacher and that involves at least half of the children in the class, such as calendar time or whole-class book reading)" (p. 149).

Despite research on the efficacy of interaction between teacher and children being placed on early childhood education, results from the current study indicated the lack of interaction in preschool classrooms. Teachers tended to compartmentalize literacy learning, and viewed circle time/large group as the opportunity to directly teach academic skills. Despite being familiar with the rhetoric of the field and the notion that children learn through play, this belief system was not consistently translated into practice. Although teachers did engage in playful methods to teach the children literacy and numeracy skills, enacted practices were not in line with the child initiated, play based foundations of the Creative Curriculum. "Early childhood educators have to look for more effective ways to provide children with sufficient opportunities to face and practice literacy patterns and targets in engaging instructional activities" (Bingham, Hall-Kenyon, \& Culatta, 2010).

Despite the fact "children who are interested and engaged during literacy related activities are likely to have more opportunities to learn and practice early reading skills"(Baroody \& Diamond, 2016, p. 147), it was observed that teachers provided less opportunities to converse with children except during book readings. The children want to feel valued and that this happens most effectively when children are given valued roles in the everyday routines of the care environment (Clark \& Moss, 2011).

Supporting the theoretical framework and sociocultural approach to literacy learning, the examination of teacher early literacy practices during data analysis evolved to become more about the teacher's overall goals for children rather than specific practices and teacher-child interactions used to help children gain the key English literacy skills including phonological awareness, alphabet knowledge and print awareness. This could be due to the lack of sophistication of the teachers in the study and their inability to name and implement research based early language and literacy practices, which emerged as a major finding of the present study. Rohde (2015) refers to a gap between research and practice of Emergent Literacy in Early Childhood Education programs. She believes that this inconsistency can be the result of the absence of knowledge and resources in providing high-quality English language learning opportunities in ECE classrooms.

While the sample was generated from a larger list of possible early childhood education programs and each of those programs was contacted with an opportunity of selection for the study, it was exclusive in that participants were from full-time privately-funded child care centers. Therefore, some bias may have occurred and characteristics of the sample, for both educators and children, were not distributed across ethnic populations, educational backgrounds, and other demographic factors that represent the general population. Therefore, the results of the study only generalize to educators and children from urban/suburban privately funded full time early childhood education centers. This is also beneficial in that it enables one to see the upper end of what is possible in a setting that included relatively few incidences of factors linked to poor teacher performance and most of the children did not possess risk factors linked to risk for lower levels of literacy learning. The results of this study are from a small sample of classrooms. Similar research with more classrooms could assist in the confirmation and the expansion of the current findings.

The overall conclusion generated from the results of the data analyses is that though teachers and preschool principals perceived that they were effectively implementing early English literacy instruction, there was actually 
a divide between what teachers believed and what they did (their actual practice) in their classrooms. In a study by Farrell and Ives (2015), the results showed that since teachers were developing in the first year of teaching, some observed practices were not expressed in the teachers' beliefs.

Furthermore, social interaction is the integral piece to the early English literacy learning and teaching. "Language use is thus not limited to ideational exchanges of messages, but is actively and agentively used to forge - achieve and renew - social relations, and to explore and manipulate the social world" (Cekaite \& Björk-Willén, 2012, p. 175).

It is important to carefully reflect on the influence, value and effect of different teacher belief systems and to understand how these can be used to develop appropriate literacy experiences for young children. Also, it is important that the circumstances under which teachers may be inhibited for using appropriate practices be known and ameliorated.

\section{Acknowledgment}

The authors extend a special thanks to the principals, teachers and the staff in Montessori and IPC preschools who participated in this study.

\section{References}

Attride-Stirling, J. (2001). Thematic networks: an analytic tool for qualitative research. Qualitative Research, I(3), 385-405. http://dx.doi.org/10.1177/146879410100100307

Baroody, A. E., \& Diamond, K. E. (2016). Associations among preschool children's classroom literacy environment, interest and engagement in literacy activities, and early reading skills. Journal of Early Childhood Research, 14(2), 146-162. http://dx.doi.org/10.1177/1476718X14529280

Bingham, G. E., Hall-Kenyon, K. M., \& Culatta, B. (2010). Systematic and engaging early literacy: Examining the effects of paraeducator implemented early literacy instruction. Communication Disorders Quarterly, 32(1), 38-49. http://dx.doi.org/10.1177/1525740109340796

Brofenbrenner, U. (1979). The ecology of human development. Cambridge, MA: Harvard University Press.

Cekaite, A., \& Björk-Willén, P. (2012). Peer group interactions in multilingual educational settings: Co-constructing social order and norms for language use. International Journal of Bilingualism, 17(2), 174-188. http://dx.doi.org/10.1177/1367006912441417

Clark, A., \& Moss, P. (2011). Listening to Young Children: The Mosaic Approach (2nd ed.). London: National Children's Bureau.

Creswell, J. W. (2012). Educational research: Planning, conducting, and evaluating quantitative and qualitative research. Pearson Education.

Dennis, L. R., \& Horn, E. (2011). Strategies for supporting early literacy development. Young Exceptional Children, 14(3), 29-40. http://dx.doi.org/10.1177/1096250611420553

Farrell, T.S.C., \& Ives, J. (2015). Exploring teacher beliefs and classroom practices through reflective practice: A case study. Language Teaching Research, 19(95), 594-610. http://dx.doi.org/10.1177/1362168814541722

Jensen, A. S. (2011). Early Literacy: Towards a unified approach for childcare and school. Journal of early Childhood Literacy, 12(3), 311-330. http://dx.doi.org/10.1177/1468798411417374

Lovelace, Sh., \& Stewart, Sh. R. (2007). Increasing print awareness in preschoolers with language impairment using non-evocative print referencing. Language, Speech, and Hearing Services in Schools, 38, 16-30. http://dx.doi.org/10.1044/0161-1461(2007/003)

Lynch, J. (2009). Preschool teachers' beliefs about children's print literacy development. Early Years, 29, 191-203. http://dx.doi.org/10.1080/09575140802628743

Malaysian International ECEC Conference. (2009). Developing human capital begins with children. Kuala Lumpur, Malaysia.

McGoun, C. (2007). The nature of research: Observation and writing. Retrieved from $\mathrm{http} / / / \mathrm{www}$.slideshare.net/cmcgoun/the-nature-of-research-observation-andwriting

Nurmi, J. E., \& Kiuru, N. (2015). Students' evocative impact on teacher instruction and teacher-child relationships: Theoretical background and an overview of previous research. International Journal of Behavioral Development, 39(5), 445-457. http://dx.doi.org/10.1177/0165025415592514 
Oldfather, P., \& Dahl, K. (1994). Toward a social constructivist reconceptualization of intrinsic motivation for literacy learning. Journal of Reading Behavior, 26(2), 139-158. http://dx.doi.org/10.1080/10862969409547843

Paciga, K. A., Hoffman, J. L., \& Teale, W. H. (2011). The national early literacy panel and preschool literacy instruction: Green lights, caution lights and red lights. Young Children, 66(6), 50-57.

Porche, M. V., Pallante, D. H., \& Snow, C. E. (2012). Professional development for reading achievement: Results from the collaborative language and literacy instruction project (CLLIP). The Elementary School Journal, 112(4), 649-671. http://dx.doi.org/10.1086/665008

Pray, L. (2010). ESL teacher education abroad and at home: A Cautionary tale. The Teacher Educator, 45, 216-229. http://dx.doi.org/10.1080/08878730.2010.488099

Rohde, L. (2015). The comprehensive emergent literacy model: Early literacy in context. Sage Open, 5(1), 1-11. http://dx.doi.org/10.1177/2158244015577664

Sandvik, J. M., Van Daal, V. HP., \& Ader, H. J. (2013). Emergent literacy: Preschool teachers' beliefs and practices. Journal of Early Childhood Literacy, 1-25.

Scull, J. A., Brown, R., \& Deans, J. (2009). Literacy in the preschool: Teachers' beliefs, theories and practices. Conference paper, Hobart, Tasmania.

Shagoury, R. (2009). Raising writers: Understanding and nurturing young children's writing development. Columbus, OH: Allyn \& Bacon.

Tseng, V., \& Seidman, E. (2007). A systems framework for understanding social settings. American Journal of Community Psychology, 39, 217-228. http://dx.doi.org/10.1007/s10464-007-9101-8

Ure, C., \& Raban, B. (2001). Teachers' beliefs and understandings of literacy in the pre-school: Pre-school literacy project stage 1. Contemporary Issues in Early Childhood, 2, 157-168. http://dx.doi.org/10.2304/ciec.2001.2.2.3

Vygotsky, L. (1978). Mind in Society. London: Harvard University Press. 


\section{Appendix A. Preschool Principal's Interview Questions}

\section{Introduction}

This appendix contains the questions asking the preschool principal.

I really appreciate for the time to meet with me. I am going to ask you some questions about your preschool teaching experiences, specifically those involving English Language Learners (ELLs). The purpose of this interview is to establish your background in language learning and teaching, and to understand your views about the role early English literacy instruction plays in language learning. There are no right or wrong answers and all responses will be confidential. Once I have transcribed your our conversation, I will show it to you. At that time, please let me know if you want to revise any of your comments.

\section{Interview Questions}

1. What is the highest level of formal education you have completed?

2. How many years have you experienced as a teacher before becoming a principal?

3. How many years have you been a principal?

4. What is your opinion regarding early English literacy?

5. How do you qualify teachers for employment?

6. What curriculum is used in your kindergarten?

7. How important is social interaction in this curriculum?

8. How is social interaction important in early English literacy instruction?

9. Are teachers guided on how to implement social interaction in their classroom?

10. Do the teachers utilize research-based methods for teaching?

11. How are your teachers professionally developed? Did they train in a specific training program for preschool teaching?

12. What is your point of view about the interaction among teacher and students?

13. What is the syllabus of teaching in your kindergarten?

14. Are teachers allowed to provide extra materials based on students' instructional needs?

15. Do the teachers should follow a same specific teaching method or approach?

Thank You for Your Participation and Candid Responses.

\section{Appendix B. Preschool Teachers' Interview Questions}

\section{Introduction}

This appendix contains the script using to introduce teachers to the interview process. In addition, it includes the script for the questions asking of each teacher.

Thank you for taking the time to meet with me. I am going to ask you some questions about your preschool teaching experiences, specifically those involving English Language Learners (ELLs). The purpose of this interview is to establish your background in language learning and teaching, and to understand your views about the role early English literacy instruction plays in language learning. Please remember that there are no right or wrong answers. The validity of this investigation depends on the extent to which your responses are open and frank, so please answer honestly and in as much detail as possible.

Feel free to ask for clarification or elaboration if you have any questions throughout the interview. Once I have transcribed your our conversation, I will show it to you. At that time, please let me know if you want to revise any of your comments.

\section{Interview Questions}

1. How did you decide to go into teaching, specifically the field of early childhood education?

2. Please indicate any teaching certificates, licenses or endorsements.

3. How long have you been a preschool teacher?

4. How long have you taught at this kindergarten? 
5. In your estimation has there been significant professional development related to preschool curriculum and instruction over the last four years?

6. Please indicate whether there has been professional development related to early English literacy over the last four years.

7. Do you believe that in kindergarten there is a suitable environment for effective teaching?

8. What do you think about early literacy instruction specifically early English literacy?

9. Please describe a typical day at the preschool?

10. Has your educational (academic program) prepared you for your work as a preschool teacher? If so, how (practice)?

11. What early literacy components do you focus on more during your teaching?

12. How do you prioritize the activities in your classroom?

13. What would you like to know more about when working in/teaching preschool (supporting literacy)?

14. How important is early English literacy (reading/writing development) in preschool?

15. Are there any changes in an Early Childhood Education preparation program you would like to see (in literacy)?

16. What do you hope your students will learn while in your classroom?

17. In your opinion, what are the essential early literacy skills students need to be successful in preschool?

18. What types of activities do you integrate into the daily curriculum that develop and support language and literacy?

19. What concerns do you have about children's early reading and writing?

20. What (if any) role do you consider you play in encouraging preschool children to read and to write?

21. What curriculum experiences (if any) do you currently offer to foster reading and writing development?

22. How do you manage to use social interaction whilst teaching?

23. What techniques or strategies do you use to engage the English learners in your classroom?

24. Is it specified in the curriculum on how to implement social interaction to develop early English literacy in young children?

25. At what age should children be encouraged to read and write in English?

26. What resources (if any) are currently available for children in your group(s) to experiment and learn about early English reading and writing?

27. How do you think young children learn to read and write?

28. Is there anything you would like to know more about young children?

29. What teaching method or approach do you implement to develop early English literacy in young children?

30. Has your approach to develop early English literacy in young children changed in any way during your career as a teacher? If so, how and why?

31. Is there anything else you would like to say about language and literacy development or your experiences?

\section{Thank You for Your Participation and Candid Responses.}

\section{Appendix C. Descriptive Observation Checklist}

\section{Learning Environment}

\section{A. Relationship to students}

Teacher establishes good eye contact with the class. She/He does not talk over their heads, to the blackboard or to just one individual.

If she/he tends to teach predominantly to one area of the classroom, she is aware of this. 
She/He makes a conscious effort at all times to pay attention to all students equally.

She/He divides the students into small groups in an organized and principled manner.

She/He recognizes that these groups should differ in size and composition, varying with the objective of the group activity.

\section{B. The Classroom}

Teacher arranges the seating in the class to suit the class activity for the day.

She/He considers the physical comfort of the room such as heat and light.

When she/he needs special materials or equipment, she/he has them set up before the class begins.

\section{Presentation}

Teacher's handwriting on the blackboard and charts is legible from all locations in the classroom.

It is large enough to accommodate students with vision impairments.

She/He speaks loudly enough to be heard in all parts of the classroom and she/he enunciates clearly.

She/He varies the exercises in class, alternating rapid and slow paced activities to keep up maximum interest level in the class.

She/He is prepared to give a variety of explanations, models or descriptions, understanding that one explanation may not be sufficient for all students.

She/He helps the students form working principles and generalizations.

Students use new skills or concepts long enough so that they are retained and thus future application is possible.

She/He plans for "thinking time" for my students so they can organize their thoughts and plan what they are going to say or do.

\section{The Individuals}

\section{A. Physical Health}

Teacher knows which students have visual or aural impairments, and have seated them as close to her/his usual teaching position as possible.

She/He is aware that a student's attention span varies from day to day depending on mental and physical health and outside distractions. She/He paces the class activities to accommodate the strengths. She/He does not continue with an activity which may exhaust or bore them.

She/He begins class with a simple activity to wake the students up and get them working together.

She/He is sensitive to individual students who have bad days. She/He does not press a student who is incapable of performing at the usual level.

$\mathrm{She} / \mathrm{He}$ tries to challenge students who are at their best.

If she/he is having a bad day and feel it might affect her/his normal teaching style, she/he lets students know so there is no misunderstanding about her/his feelings for them.

\section{B. Aptitude and Perception}

Teacher is aware that students learn differently.

Her/His exercises are varied, some ore visual, aural, oral and kinaesthetic. She/He provides models, examples, and experiences to maximize learning in each of these areas.

She/He knows basic concepts in the memory process. When applicable, she/he makes use of techniques such as backward build-up and association to aid students in rapid skill acquisition. 


\section{Reinforcement}

Teacher tells students when they have done well, but she/he does not let praise become mechanical.

She/He finishes the class period in a way which will review the new concepts presented during the class period. Her/His students can immediately evaluate their understanding of those concepts.

The tests are well-planned and produced.

She/He makes the system of grading clear to the students so that there are no misunderstandings of expectations.

\section{Development}

Teacher keeps up to date on new techniques in the ESL profession by attending conferences and workshops and by reading pertinent professional articles and books.

She/He realizes that there is no one right way to present any lesson. She/He tries new ideas where and when they seem appropriate.

She/He observes other ESL teachers so that she/he can get other ideas and compare them to her/his own teaching style. She/He wants to have several ideas for teaching any one concept.

\section{The Activity}

\section{Appendix D. The Focused Observation Checklist}

\section{A. Interaction}

Teacher minimizes her/his role in conducting the activities.

She/He organizes the activities so they are suitable for real interaction among the students.

The activities maximize student involvement.

The activities promote spontaneity or experimentation on the part of the learner.

The activities generally transfer attention away from "self" and outward toward a "task".

The activities are organized to insure a high success rate, leaving enough room for error to make the activity challenging.

$\mathrm{She} / \mathrm{He}$ is not overly concerned with error correction. She/He concentrates on what the students are saying (content).

\section{B. Language}

The activity is focused.

The content or the skill presented will be easily transferrable for use outside the class.

The activity is geared to the proficiency level of my class or slightly beyond.

The content of the activity is not too sophisticated for my students.

Teacher makes the content of the activity relevant and meaningful to the students' world.

Christison, M.A. and Bassano, S. 1983. TESOL Convention, Toronto

\section{Interactions during Literacy Activities}

Teacher promotes the students to attend during literacy activities using:

- eye gaze

- gestures

- voice

- personal communication device

She/He helps the students to attend to (by reaching, pointing or looking) to:

- pictures

- symbols 
- text

She/He guides students to demonstrate understanding or personal connection during favourite part of story by:

- commenting on and/or

- relating to personal experiences

- responding to questions about story

- asking questions about story

She/He promotes the students to retell a part of the story

- with an activity (e.g., arrange picture cards, act out, retell in own words)

- in a sequence

\section{Interactions with Symbols/Print}

Teacher encourages the students to demonstrate awareness of print by:

- attending

- eye gaze

- pointing

- vocalizations

- talking

She/He helps students to connect print to speech/language

She/He guides them to understand basic concept of printed word (e.g., by connecting picture or object with printed word)

She/He encourages them to recognize words in print in isolation or in context

\section{Alphabet Knowledge}

Teacher encourages students to:

explore alphabet materials

know that printed/tactual letters are different from pictures and other representations recognize first letter in own name

identify specific letters in:

- own name

- other important names

- high frequency words

Teacher helps students to:

recognize other letters in other words

identify name of many letters (indicate number of letters)

\section{Phonological Awareness}

Teacher assures that students:

participate in word play such as finger plays

follow rhythmic patterns in poems, music and stories

recognize basic sounds of some letters (indicate number or specific letters)

repeat rhythmic patterns in poems, music and stories

demonstrate awareness that different words begin with the same sound

identify initial letter sounds of at least 20 letters 


\section{Appendix E. Documents}
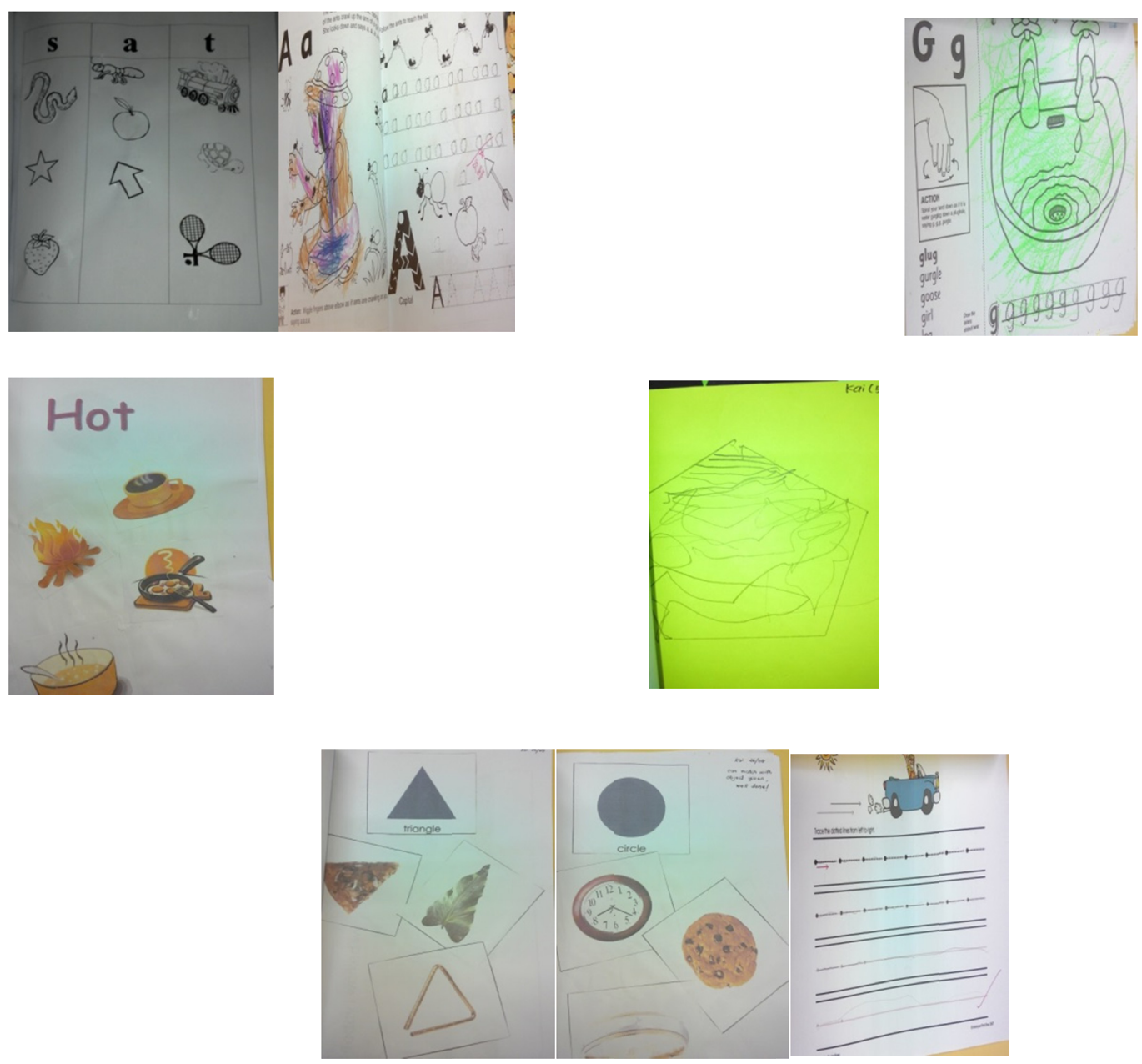

\section{Copyrights}

Copyright for this article is retained by the author(s), with first publication rights granted to the journal.

This is an open-access article distributed under the terms and conditions of the Creative Commons Attribution license (http://creativecommons.org/licenses/by/4.0/). 